
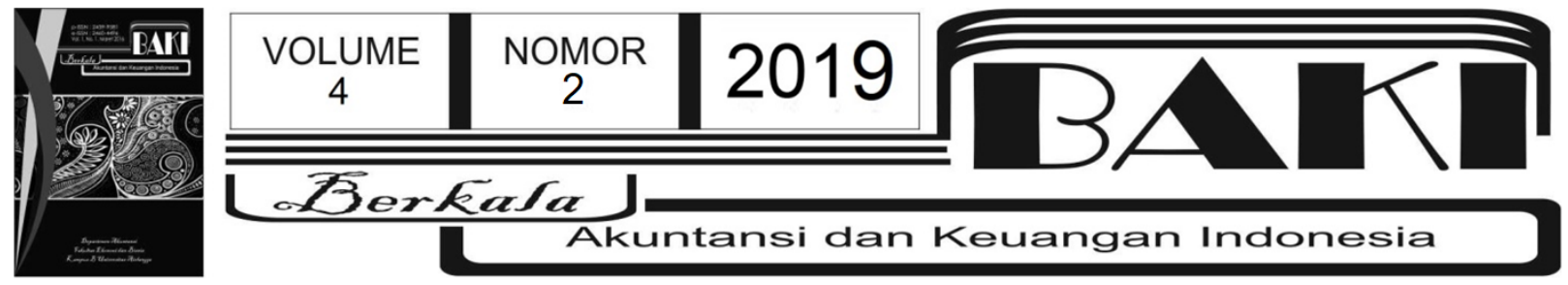

\title{
Pengaruh ITO, CR, DER, TATO dan WCTO Terhadap ROE Pada Perusahaan Aneka Industri Terdaftar Di BEI
}

\author{
Jessica $^{1,2}$, Wirda Lilia ${ }^{1,3}$, Cherlyn Leonardy,4, Meiluawaty Kartika ${ }^{1,5}$, \\ Nehemia Panggabean ${ }^{1,6}$
}

\author{
${ }^{1}$ Universitas Prima Indonesia \\ 2jejetan17@ymail.com \\ 3liliawirda@ymail.com \\ 4cherlynleonardy@ymail.com \\ 5mel.rajamarga@gmail.com \\ ${ }^{6}$ nehemia.gabe@gmail.com
}

INFO ARTIKEL

Histori Artikel:

Tanggal Masuk 20 Oktober 2019

Tanggal Diterima 30 November 2019

Tersedia Online 31 Desember 2019

Kata Kunci:

Inventory Turnover,

Current Ratio,

Debt To Equity,

Total Assets Turnover, Working Capital Turnover, Return on Equity.

\section{A BSTRAK}

Penelitian ini bertujuan untuk menganalisis pengaruh dari inventory turnover, current ratio, debt to equity ratio, total assets turnover, dan working capital turnover terhadap return on equity pada perusahaan aneka industri yang terdaftar di Bursa Efek Indonesia. Penelitian ini menggunakan metode pendekatan kuantitatif. Populasi dalam penelitian ini adalah semua perusahaan aneka industri yang terdaftar dalam Bursa Efek Indonesia periode tahun 2014-2017. Teknik pengambilan sampel yang digunakan adalah purposive sampling dengan 64 perusahaan sebagai sampel. Penelitian ini menggunakan data sekunder yang diambil dari Bursa Efek Indonesia. Penelitian ini dianalisis dengan menggunakan analisis linear regresi berganda. Koefisien determinasi dari return on equity sebesar $42,8 \%$ yang dipengaruhi oleh inventory turnover, current ratio, debt to equity ratio, total assets turnover, dan working capital turnover. Hasil penelitian menunjukkan bahwa inventory turnover, current ratio, debt to equity ratio, total assets turnover, dan working capital turnover secara simultan berpengaruh terhadap return on equity. Secara parsial, inventory turnover, current ratio, dan working capital turnover tidak berpengaruh terhadap return on equity, debt to equity ratio berpengaruh negatif dan signifikan terhadap return on equity, dan total assets turnover berpengaruh secara positif dan signifikan terhadap return on equity. 


\section{Pendahuluan}

Sektor industri berperan penting karena memiliki beberapa keunggulan dalam akselerasi pembangunan ekonomi di berbagai negara. Sektor industri memberikan kontribusi dalam peningkatan penyerapan tenaga kerja, nilai tambah (value added), investasi, dan penerimaan devisa. Industri manufaktur yang terus bertumbuh dan berkembang menimbulkan semakin pesatnya laju perekonomian dan meningkatnya permintaan konsumen terhadap produk. Hal ini memicu persaingan industri manufaktur yang ada di Indonesia semakin ketat.

Aneka perusahaan manufaktur memiliki tingkat permintaan yang fluktuatif atau tidak tetap, sehingga sektor aneka industri tergolong sektor bersiklus, terutama di industri otomotif. Sektor ini memiliki beraneka ragam variasi produk dan mampu memberikan keuntungan pada pengguna, sehingga sektor aneka industri dipercaya sebagai sektor yang dapat menuntun sektor lainnya menuju perekonomian yang progresif.

Sektor aneka industri terbilang sebagai sektor yang rawan hancur karena ketika terjadi krisis, permintaan produk akan melemah yang mengakibatkan kerugian bagi perusahaan. Namun ketika perekonomian menanjak, sektor ini akan turut menanjak. Di Indonesia, perkembangan sektor aneka industri bertumbuh sangat pesat. Walaupun sempat melemah di tahun 2015 seperti yang diujar Menteri Perindustrian saat itu, Saleh Husin "Tahun 2015 memang tahun yang sulit. Banyak penurunan di sektor industri. Ini lantaran faktor ekonomi global di tahun 2015 mengalami pelambatan. Ini melambat (pertumbuhan industri) karena pertumbuhan (ekonomi) di dalam negeri dipengaruhi ekonomi global, pengaruhi di dalam negeri, sehingga mengurangi permintaan." Namun sektor ini tetap mampu memberikan kontribusi yang cukup besar bagi perekonomian Indonesia.

Seiring berkembangnya sektor aneka industri, semakin berkembang juga persaingan karena jumlah perusahaan di sektor aneka industri semakin banyak. Situasi persaingan perusahaan yang semakin naik menuntut perusahaan untuk menjadi lebih baik lagi dan menyebabkan tujuan suatu perusahaan tidak mudah untuk diraih. Secara umum, tujuan perusahaan ialah untuk mendapatkan laba agar perusahaan dapat terus beroperasi dan dapat terus mengembangkan perusahaan menjadi lebih besar untuk mempertahankan eksistensinya. Tingkat profit perusahaan dapat memperhatikan rasio profitabilitas agar perusahaan mengetahui petumbuhannya dalam jangka waktu tertentu, baik mengalami kenaikan ataupun penurunan laba.

Profitabilitas perusahaan dipengaruhi oleh beberapa faktor. Salah satunya adalah tingkat inventory turnover yang menunjukkan persediaan tersebut berganti dalam arti dibeli dan dijual kembali. Perusahaan industri tetap menyuplai persediaan untuk melakukan kegiatan produksi ataupun penjualan. Perusahaan yang mampu mengelola persediaan dengan efisien 
merupakan perusahaan yang menguntungkan atau perusahaan dengan profitabilitas yang tinggi.

Tinggi rendahnya nilai current ratio berpengaruh bagi profitabilitas perusahaan. Rasio ini menggambarkan kemampuan aset lancar menutupi hutang yang jatuh tempo kurang dari satu tahun. Tingginya nilai current ratio berdampak bagi kreditur karena disimpulkan segala kewajiban dapat dilunasi. Nilai current ratio yang rendah akan beresiko namun menunjukkan perusahaan menggunakan aset lancar dengan efektif untuk menghasilkan laba.

Debt to equity ratio sangat berpengaruh terhadap profitabilitas perusahaan, karena rasio ini menerangkan kemampuan perusahaan memenuhi kewajiban jangka panjangnya. Perusahaan yang semakin berkembang akan membutuhkan anggaran yang lebih banyak dari berbagai pihak untuk kegiatan operasional yang sangat mempengaruhi profitabilas perusahaan. Jika sumber dana eksternal perusahaan tidak dipedulikan dan dibiarkan meningkat, maka akan terjadi penurunan profitabilitas perusahaan karena menyebabkan beban bunga naik dan tidak berdampak baik untuk perusahaan.

Total assets turnover mengukur penjualan yang didatangkan dari efektivitas pengelolaan seluruh aset perusahaan. Jika nilai rasio ini tinggi berarti seluruh aset digunakan dengan baik untuk menunjang aktivitas penjualan guna memperoleh laba. Kondisi ini menerangkan bahwa adanya pengaruh positif total assets turnover terhadap profitabilitas .

Modal kerja merupakan anggaran yang berputar secara permanen guna mendukung aktivitas perusahaan. Anggaran atau dana ini harus dikelola secara efektif agar menunjukkan pengelolaan yang produktif. Modal kerja yang kurang bisa mengidentifikasikan kemunduran atau kegagalan perusahaan dalam tingkat pengembalian modal dan menurunnya profitabilitas perusahaan.

Berdasarkan latar belakang diatas, peneliti tertarik untuk mengambil judul "Pengaruh Inventory Turnover, Current Ratio, Debt to Equity Ratio, Total Assets Turnover, dan Working Capital Turnover terhadap Return on Equity pada Perusahaan Aneka Industri yang Terdaftar di Bursa Efek Indonesia (BEI)".

\section{Tinjauan Pustaka}

\subsection{Teori Pengaruh Inventory Turnover Terhadap Return on Equity}

Menurut Mega (2017), dalam perusahaan persediaan termasuk salah satu faktor penting. Perputaran persediaan sangat membantu suatu perusahaan dalam menggerakkan usaha. Perputaran persediaan diukur dari jumlah dana yang tercantum dalam persediaan dalam suatu jangka waktu.

Menurut Susanti (2017), tingkat perputaran persediaan yang semakin rendah akan mempengaruhi modal dan menyebabkan penumpukan persediaan digudang semakin tinggi. 
Perputaran persediaan digunakan untuk mengetahui sejauh mana suatu perusahaan mampu mengelola persediaannya seefisien dan seefektif mungkin.

Menurut Susilawati,dkk (2017), kemampuan perusahaan dalam menghasilkan pendapatan atau laba selalu tidak berpengaruh secara signifikan oleh perputaran persediaan. Tetapi bukan berarti tidak berpengaruh sama sekali, semakin tinggi laba yang kita dapatkan akan mempengaruhi juga perputaran persediaan walaupun tidak banyak.

$\mathrm{H} 1$ : Inventory turnover berpengaruh terhadap return on equity.

\subsection{Teori Pengaruh Current Ratio Terhadap Return on Equity}

Menurut Pongrangga,dkk (2015), suatu perusahaan biasanya menggunakan current ratio untuk menilai kemampuan perusahaan dalam membayar seluruh hutang jangka pendeknya yang akan jatuh tempo. Perbandingan antara aktiva lancar dan liabilitas lancar yang besar menggambarkan apakah perusahaan mampu membayar hutang jangka pendeknya semakin besar. Namun tingkat rasio lancar tinggi berarti perusahaan tidak cukap dalam mengelola aktiva lancar secara efektif. Hal ini menjadikan kecilnya nilai return on equity, dimana berkurangnya laba yang diperoleh perusahaan.

Menurut Pratomo (2017), semakin rendah current ratio menyebabkan suatu perusahaan tidak mampu membayar utang lancarnya yang berarti peningkatan laba perusahaan tersebut berpengaruh secara negatif.

Menurut Hantono (2015), current ratio digunakan perusahaan untuk mengetahui kemampuannya dalam menyanggupi kewajiban jangka pendeknya. Nilai current ratio yang rendah menerangkan adanya masalah dalam pembubaran perusahaan (likuidasi) namun jika nilai current ratio terlampau tinggi menunjukkan banyaknya dana yang menganggur sehingga laba juga menurun.

$\mathrm{H} 2$ : Current ratio berpengaruh terhadap return on equity.

\subsection{Teori Pengaruh Debt to Equity Ratio Terhadap Return on Equity}

Menurut Pongrangga,dkk (2015), bertambah tingginya nilai debt to equity ratio menyebabkan laba perusahaan semakin menurun, yang mana berdampak pada kemampuan perusahaan dalam menghasilkan laba atas dana perusahaan.

Menurut Pratomo (2017), salah satu hal yang tak kalah penting adalah kinerja perusahaan karena dapat mengetahui kondisi suatu perusahaan tersebut mengalami penurunan atau peningkatan. Dengan menurunnya DER tiap tahunnya menandakan beban hutang yang ditanggung semakin kecil dan itu dapat menambah laba yang akan dihasilkan perusahaan. 
Menurut Hantono (2015), debt to equity ratio dapat digunakan untuk mengetahui bagaimana kesanggupan modal pemilik dapat memenuhi utang-utang dari luar. Dengan meningkatnya jumlah debt to equity ratio memperlihatkan makin besarnya depedensi perusahaan terhadap pihak asing yang berarti makin membesar juga tingkat risiko perusahaan yang akan mempengaruhi penurunan harga saham.

H3 : Debt to equity ratio berpengaruh terhadap return on equity.

\subsection{Teori Pengaruh Total Assets Turnover Terhadap Return on Equity}

Menurut Hendawati (2017), apabila tingkat efisiensi penggunaan aset semakin meningkat maka pengembalian dana dalam bentuk kas juga semakin cepat. Namun apabila tingkat efisiensi penggunaan aset semakin menurun merupakan tanda bahwa perusahaan tersebut tidak berfungsi sebagaimana seharusnya.

Menurut Susilawati,dkk (2017), total assets turnover kurang berpengaruh cukup kuat terhadap return on equity, yang menandakan bahwa hasil penjualan tidak berpengaruh banyak dengan total aset yang dipunyai perusahaan.

Menurut Pongrangga,dkk (2015), total assets turnover menunjukkan kapabilitas perusahaan dalam memaksimalkan aktiva yang ada untuk mendatangkan penjualan.

H4 : Total assets turnover berpengaruh terhadap return on equity.

\subsection{Teori Pengaruh Working Capital Turnover Terhadap Return on Equity}

Menurut Nopiana, dkk (2015), working capital turnover berefek cukup besar terhadap return on equity, dengan semakin pendek periode working capital turnover maka tingkat profitabilitas akan semakin meningkat.

Menurut Pratomo (2017), apabila sebuah perusahaan dapat mengelola perputaran modal kerjanya secara maksimal maka hasil dari perputaran tersebut bisa dipakai guna menunjang aktivitas perusahaan yang lain seperti dalam bentuk kas.

Menurut Hantono (2015), semakin tinggi working capital turnover, semakin baik pula posisi pemilik dari perusahaan. Hal ini menunjukkan semakin baiknya efisiensi dalam penggunaan modal sendiri.

H5 : Working capital turnover berpengaruh terhadap return on equity.

\section{Metodologi Penelitian}

Penelitian ini menerapkan metode penelitian kuantitatif. Data yang diteliti merupakan data sekunder yang ada pada laporan keuangan yang diterbitkan oleh Bursa Efek Indonesia (BEI). Sumber data didapatkan dengan studi dokumentasi. Jenis penelitian yang digunakan adalah deskriptif dan sifat penelitian ini adalah hubungan kausal. 


\subsection{Populasi}

Populasi yang diambil oleh peneliti adalah perusahaan aneka industri yang terekam di Bursa Efek Indonesia (BEI) serta laporan keuangan yang bersumber dari https://idx.co.id/. Peneliti mengambil 44 perusahaan sebagai populasi penelitian.

\subsection{Sampel}

Sampel adalah sebagian yang dieliminasi dari populasi sesuai dengan tolak ukur yang peneliti tentukan. Teknik pengambilan sampel dalam penelitian ini adalah metode sampling purposive. Berdasarkan pertimbangan terdaftar di Bursa Efek Indonesia (BEI) selama periode 2014-2017, menerbitkan laporan keuangan secara rutin, dan memiliki laba positif, maka terdapat 16 perusahaan sampel dalam penelitian ini.

\subsection{Definisi Operasional Variabel Penelitian}

Variabel pada penelitian ini mencakup lima variabel independen $(X)$ dan satu variabel dependen (Y).

\subsubsection{Inventory Turnover (X1)}

Menurut Kasmir (2015:180), inventory turnover ditujukan untuk mengukur dana untuk persediaan berputar berapa kali dalam suatu periode. Rumus yang digunakan :

$$
\text { Inventory Turnover }=\frac{\text { Penjualan }}{\text { Persediaan }}
$$

\subsubsection{Current Ratio (X2)}

Menurut Fahmi (2017:121), rasio lancar menggambarkan kemampuan perusahaan secara keseluruhan memenuhi hutang yang akan jatuh tempo. Rasio ini dirumuskan sebagai berikut:

$$
\text { Current Ratio }=\frac{\text { Aktiva Lancar }}{\text { Hutang Lancar }}
$$




\subsubsection{Debt to Equity Ratio (X3)}

Menurut Fahmi (2017:128), debt to equity ratio digunakan untuk menganalisis laporan keuangan dalam menunjukkan ketersediaan jaminan kepada kreditor. Rasio diformulakan sebagai berikut:

$$
\text { Debt to Equity Ratio }=\frac{\text { Total Hutang }}{\text { Modal Sendiri }}
$$

\subsubsection{Total Assets Turnover (X4)}

Menurut Kasmir (2015:137), total assets turnover berguna untuk memperkirakan hasil dari penjualan perusahaan terhadap nilai aset milik perusahaan. Rasio ini dapat dihitung menggunakan rumus:

$$
\text { Total Assets Turnover }=\frac{\text { Penjualan }}{\text { Total Aset }}
$$

\subsubsection{Working Capital Turnover (X5)}

Menurut Kasmir (2015:182), working capital turnover guna mengukur nilai efisiensi modal kerja suatu perusahaan dalam masa tertentu. Rasio ini dapat dihitung menggunakan rumus:

$$
\text { Working Capital Turnover }=\frac{\text { Penjualan Bersih }}{\text { Modal Kerja }}
$$

\subsubsection{Return on Equity $(Y)$}

Menurut Fahmi (2017:137), return on equity menunjukkan potensi perusahaan dalam mengoperasikan sumber dayanya untuk mendatangkan keuntungan atas ekuitas. Rasio diperhitungkan dengan rumus:

$$
\text { Return on Equity }=\frac{\text { Laba setelah pajak }}{\text { Modal Sendiri }}
$$




\subsection{Teknik Analisis Data}

\subsubsection{Uji Asumsi Klasik}

\section{a. Uji Normalitas}

Menurut Ghozali (2015:134), uji normalitas dilakukan untuk menguji model regresi, variabel pengganggu atau residual memiliki distribusi normal. Dalam menganalisis data apakah berdistribusi normal atau tidak, terdapat dua cara yaitu analisis grafik dan uji statistik.

\section{b. Uji Multikolinearitas}

Menurut Ghozali (2015:103), uji multikolinearitas dilakukan untuk menguji apakah ditemukan adanya korelasi antar variabel bebas (independen) dalam model regresi.

\section{c. Uji Autokorelasi}

Menurut Ghozali (2015:107), uji autokorelasi dilakukan untuk menguji apakah dalam model regresi linear terjadi korelasi antara kesalahan pengganggu pada suatu periode (t) dengan kesalahan pengganggu pada periode sebelumnya (t-1).

\section{d. Uji Heteroskedastisitas}

Menurut Ghozali (2015:134), uji heteroskedastisitas dilakukan untuk menguji apakah ada ketidakselarasan variance dari residual satu pengamatan ke pengamatan yang lain.

\subsubsection{Model Analisis Data Penelitian}

\section{a. Analisis Regresi Berganda}

Untuk mengetahui pengaruh variabel bebas $(\mathrm{X})$ dan variabel terikat $(\mathrm{Y})$, rumus analisis linear berganda digunakan sebagai berikut:

$$
\mathrm{Y}=\mathrm{a}+\mathrm{b}_{1} \mathrm{X}_{1}+\mathrm{b}_{2} \mathrm{X}_{2}+\mathrm{b}_{3} \mathrm{X}_{3}+\mathrm{b}_{4} \mathrm{X}_{4}+\mathrm{b}_{5} \mathrm{X}_{5}+\mathrm{e}
$$

Untuk penelitian ini diperoleh keterangan sebagai berikut:

$$
\begin{aligned}
& \mathrm{Y}=\text { Return on Equity } \\
& \mathrm{a}=\text { Konstanta } \\
& \mathrm{b}_{1}=\text { Koefisien Regresi Variabel } \mathrm{X} \\
& \mathrm{b}_{2}=\text { Koefisien Regresi Variabel } \mathrm{X} \\
& \mathrm{b}_{3}=\text { Koefisien Regresi Variabel } \mathrm{X} \\
& \mathrm{b}_{4}=\text { Koefisien Regresi Variabel } \mathrm{X} \\
& \mathrm{b}_{5}=\text { Koefisien Regresi Variabel } \mathrm{X}
\end{aligned}
$$


$\mathrm{X}_{1}=$ Variabel Inventory Turnover

$\mathrm{X}_{2}=$ Variabel Current Ratio

$\mathrm{X}_{3}=$ Variabel Debt to Equity Ratio

$\mathrm{X}_{4}=$ Variabel Total Assets Turnover

$\mathrm{X}_{5}=$ Variabel Working Capital Turnover

e $=$ Presentase Kesalahan $(0,05)$

b. Uji Koefisien Determinasi $\left(R^{2}\right)$

Menurut Ghozali (2015:95), koefisien determinasi menguji kemampuan variabel bebas menjelaskan variabel terikat. Nilai koefisien determinasi diantara satu dan nol. Nilai yang semakin besar (mendekati satu) akan menggambarkan kemampuan variabel bebas dalam mendeskripsikan variabel terikatnya baik

\section{c. Uji F (Simultan)}

Uji simultan bertujuan untuk menunjukkan kemampuan seluruh variabel bebas pengaruh secara bersamaan terhadap variabel terikat. Uji F dilakukan dengan cara membandingkan nilai $F$ hasil perhitungan dengan nilai $F$ menurut tabel. Apabila nilai $F$ hitung lebih besar dari nilai $F$ tabel, maka hipotesis alternatif bahwa semua variabel bebas mempengaruhi secara serentak mempengaruhi variabel terikat.

d. Uji T (Parsial)

Uji parsial bermaksud untuk menerangkan pengaruh variabel independen secara individual terhadap variabel dependen. Cara melakukan uji T adalah dengan membandingkan nilai statistik $t$ dengan titik kritis menurut tabel. Apabila nilai statistik t hitung lebih besar dari nilai $\mathrm{t}$ tabel, maka hipotesis alternatif bahwa suatu variabel bebas mempengaruhi variabel terikat akan diterima. 


\section{Analisis dan Pembahasan}

\subsection{Hasil Analisis Data}

\subsubsection{Persamaan Regresi Linear Berganda}

Tabel 4.5 Hasil Analisis Regresi Linear Berganda

\begin{tabular}{|c|c|c|c|c|c|c|c|}
\hline & & & Coefficients & & & & \\
\hline \multirow[t]{2}{*}{ Model } & \multicolumn{2}{|c|}{$\begin{array}{c}\text { Unstandardized } \\
\text { Coefficients }\end{array}$} & \multirow{2}{*}{$\begin{array}{c}\begin{array}{c}\text { Standardized } \\
\text { Coefficients }\end{array} \\
\text { Beta }\end{array}$} & \multirow[t]{2}{*}{$t$} & \multirow[t]{2}{*}{ Sig. } & \multicolumn{2}{|c|}{ Collinearity Statistics } \\
\hline & $\mathrm{B}$ & Std. Error & & & & Tolerance & VIF \\
\hline (Constant) & -169 & .179 & & -.942 & .350 & & \\
\hline SQRT_ITO & .035 & .048 & .089 & .732 & .467 & .660 & 1.515 \\
\hline SQRT_CR & .120 & .078 & .201 & 1.538 & .130 & .570 & 1.753 \\
\hline SQRT_DER & -.230 & .075 & -.391 & -3.080 & .003 & .601 & 1.664 \\
\hline SQRT_TATO & .493 & .118 & .502 & 4.184 & .000 & .674 & 1.484 \\
\hline SQRT_WCTO & -.005 & .022 & -.033 & -.209 & .836 & 395 & 2.534 \\
\hline
\end{tabular}

a. Dependent Variable: SQRT_ROE

Berdasarkan tabel diatas, persamaan regresi linear berganda diformulakan sebagai berikut:

$$
\text { ROE }=-0,169+0,035 \mathrm{ITO}+0,120 \mathrm{CR}-0,230 \mathrm{DER}+0,493 \mathrm{TATO}-0,005 \mathrm{WCTO}
$$

\subsubsection{Uji Koefisien Determinasi $\left(R^{2}\right)$}

Tabel 4.6 Hasil Uji Koefisien Determinasi

\begin{tabular}{|l|r|r|r|r|r|}
\hline Model & $\mathrm{R}$ & $\mathrm{R}$ Square & $\begin{array}{c}\text { Adjusted R } \\
\text { Square }\end{array}$ & $\begin{array}{c}\text { Std. Error of the } \\
\text { Estimate }\end{array}$ & Durbin-Watson \\
\hline 1 & $.690^{\mathrm{a}}$ & .477 & .428 & .16049 & 1.836 \\
\hline
\end{tabular}

a. Predictors: (Constant), SQRT_WCTO, SQRT_ITO, SQRT_TATO, SQRT_DER, SQRT_CR

Berdasarkan tabel diatas, hasil uji koefisien determinasi Adjusted $R$ Square $\left(\mathrm{R}^{2}\right)$ dapat dibaca sebesar 0,428 atau sama dengan $42,8 \%$. Hal ini berarti $42,8 \%$ variasi variabel return on equity sudah dijelaskan oleh variabel independen inventory turnover, current ratio, debt to equity ratio, total assets turnover, dan working capital turnover. Selebihnya sebesar $57,2 \%$ dijelaskan oleh variabel lain.

\subsubsection{Uji F (Simultan)}

Tabel 4.7 Hasil Uji F (Simultan)

\begin{tabular}{|ll|r|r|r|r|r|}
\hline Model & & Sum of Squares & \multicolumn{1}{|c|}{ df } & Mean Square & F & Sig. \\
\hline \multirow{4}{*}{1} & Regression & 1.266 & 5 & .253 & 9.832 & $.000^{\mathrm{s}}$ \\
& Residual & 1.391 & 54 & .026 & & \\
& Total & 2.657 & 59 & & & \\
\hline
\end{tabular}

a. Dependent Variable: SQRT_ROE

b. Predictors: (Constant), SQRT_WCTO, SQRT_ITO, SQRT_TATO, SQRT_DER, SQRT_CR 
Dari tabel diatas, dapat diketahui bahwa nilai $F_{\text {hitung }}$ sebesar 9,832 dan $F_{\text {tabel }}$ sebesar 2,39. Maka dapat disimpulkan bahwa $F_{\text {hitung }}>F_{\text {tabel }}$ yaitu 9,832 $>2,39$. Hal ini berarti variabel inventory turnover, current ratio, debt to equity ratio, total assets turnover, dan working capital turnover secara simultan berpengaruh positif dan signifikan terhadap return on equity.

\subsubsection{Uji T (Parsial)}

Tabel III.8 Hasil Uji T (Parsial)

\begin{tabular}{|c|c|c|c|c|c|c|c|}
\hline \multirow{3}{*}{ Model } & & & Coefficients & & & & \\
\hline & \multicolumn{2}{|c|}{$\begin{array}{l}\text { Unstandardized } \\
\text { Coefficients }\end{array}$} & \multirow{2}{*}{\begin{tabular}{|c} 
Standardized \\
Coefficients
\end{tabular}} & \multirow[t]{2}{*}{$\mathrm{t}$} & \multirow[t]{2}{*}{ Sig. } & \multicolumn{2}{|c|}{ Collinearity Statistics } \\
\hline & $\mathrm{B}$ & Std. Error & & & & Tolerance & VIF \\
\hline (Constant) & -169 & .179 & & -.942 & .350 & & \\
\hline SQRT_ITO & .035 & .048 & .089 & .732 & .467 & .660 & 1.515 \\
\hline SQRT_CR & .120 & .078 & .201 & 1.538 & .130 & .570 & 1.753 \\
\hline SQRT_DER & -.230 & .075 & -.391 & -3.080 & .003 & .601 & 1.664 \\
\hline SQRT_TATO & -493 & .118 & .502 & 4.184 & .000 & .674 & 1.484 \\
\hline SQRT_WCTO & -.005 & .022 & -.033 & -.209 & .836 & .395 & 2.534 \\
\hline
\end{tabular}

a. Dependent Variable: SQRT_ROE

Nilai $t_{\text {tabel }}$ adalah sebesar 2,00488 dengan nilai signifikan 0,05 . Hasil pengujian statistik secara parsial sebagai berikut:

1. Variabel inventory turnover memiliki nilai $t_{\text {hitung }}$ sebesar 0,732 dengan nilai signifikan 0,467 .

Dengan demikian maka nilai $t_{\text {hitung }}<t_{\text {tabel }}$ yang artinya inventory turnover secara parsial tidak berpengaruh signifikan terhadap return on equity.

2. Variabel current ratio memiliki nilai $t_{\text {hitung }}$ sebesar 1,538 dengan nilai signifikan 0,130 . Dengan demikian maka nilai $t_{\text {hitung }}<t_{\text {tabel }}$ yang artinya current ratio secara parsial tidak berpengaruh signifikan terhadap return on equity.

3. Variabel debt to equity ratio memiliki nilai $t_{\text {hitung }}$ sebesar $-3,080$ dengan nilai signifikan 0,003 . Dengan demikian maka nilai $t_{\text {hitung }}<t_{\text {tabel }}$ yang artinya debt to equity ratio secara parsial berpengaruh negatif dan signifikan terhadap return on equity.

4. Variabel total assets turnover memiliki nilai $t_{\text {hitung }}$ sebesar 4,184 dengan nilai signifikan 0,000 . Dengan demikian maka nilai $t_{\text {hitung }}>t_{\text {tabel }}$ yang artinya total assets turnover secara parsial berpengaruh positif dan signifikan terhadap return on equity.

5. Variabel working capital turnover memiliki nilai $t_{\text {hitung }}$ sebesar -0,209 dengan nilai signifikan 0,836 . Dengan demikian maka nilai $t_{\text {hitung }}<t_{\text {tabel }}$ yang artinya working capital turnover secara parsial tidak berpengaruh signifikan terhadap return on equity.

\subsection{Pembahasan Hasil Penelitian}

\subsubsection{Pengaruh Inventory Turnover terhadap Return on Equity}


Hasil pengujian hipotesis secara parsial menunjukkan bahwa inventory turnover secara parsial tidak berpengaruh signifikan terhadap return on equity pada perusahaan aneka industri yang terdaftar di Bursa Efek Indonesia (BEI) periode 2014-2017. Hasil penelitian ini sejalan dengan penelitian Mega (2017) dan Susanti (2017) yang menyatakan bahwa inventory turnover tidak memiliki pengaruh yang signifikan terhadap return on equity. Akan tetapi, hasil penelitian ini bertentangan dengan penelitian Susilawati,dkk (2017) yang menyatakan bahwa inventory turnover berpengaruh positif namun tidak signifikan terhadap return on equity.

\subsubsection{Pengaruh Current Ratio terhadap Return on Equity}

Hasil pengujian hipotesis secara parsial menunjukkan bahwa current ratio secara parsial tidak berpengaruh signifikan terhadap return on equity pada perusahaan aneka industri yang terdaftar di Bursa Efek Indonesia (BEI) periode 2014-2017. Hasil penelitian ini sejalan dengan hasil penelitian Pongrangga,dkk (2015) dan Pratomo (2017) yang menyatakan bahwa variabel current ratio tidak memiliki pengaruh yang signifikan terhadap return on equity, namun bertentangan dengan penelitian Hantono (2015) yang menyatakan bahwa variabel current ratio memiliki pengaruh yang signifikan terhadap return on equity.

\subsubsection{Pengaruh Debt to Equity Ratio terhadap Return on Equity}

Hasil pengujian hipotesis secara parsial menunjukkan bahwa debt to equity ratio secara parsial berpengaruh negatif dan signifikan terhadap return on equity pada perusahaan aneka industri yang terdaftar di Bursa Efek Indonesia (BEI) periode 2014-2017. Hasil penelitian ini sejalan dengan penelitian Hantono (2015) dan Pongrangga,dkk (2015) yang menyatakan bahwa variabel debt to equity ratio memiliki pengaruh yang signifikan terhadap return on equity, namun bertentangan dengan hasil penelitian Pratomo (2017) yang menyatakan bahwa variabel debt to equity ratio tidak berpengaruh signifikan terhadap return on equity.

\subsubsection{Pengaruh Total Assets Turnover terhadap Return on Equity}

Hasil pengujian hipotesis secara parsial menunjukkan bahwa total assets turnover secara parsial berpengaruh positif dan signifikan terhadap return on equity pada perusahaan aneka industri yang terdaftar di Bursa Efek Indonesia (BEI) periode 2014-2017. Hasil penelitian ini sejalan dengan hasil penelitian Pongrangga,dkk (2015) dan Susilawati,dkk (2017) menyatakan bahwa total assets turnover memiliki pengaruh yang signifikan terhadap return on equity, namun bertentangan dengan penelitian Hendrawati (2017) menyatakan bahwa total assets turnover secara signifikan tidak mempunyai pengaruh terhadap return on equity.

\subsubsection{Pengaruh Working Capital Turnover terhadap Return on Equity}


Hasil pengujian hipotesis secara parsial menunjukkan bahwa working capital turnover secara parsial tidak berpengaruh signifikan terhadap return on equity pada perusahaan aneka industri yang terdaftar di Bursa Efek Indonesia (BEI) periode 2014-2017. Hasil penelitian ini sejalan dengan penelitian Nopita \& Ernawati (2018) yang menyatakan bahwa working capital turnover tidak berpengaruh terhadap return on equity, namun bertentangan dengan penelitian Sanada (2016) dan Felany \& Worokinasih (2018) yang menyatakan bahwa adanya pengaruh signifikan antara working capital turnover terhadap return on equity.

\section{Kesimpulan, Keterbatasan, dan Saran}

\subsection{Kesimpulan}

Hasil analisis secara parsial menunjukkan bahwa inventory turnover, current ratio, dan working capital turnover tidak berpengaruh terhadap return on equity pada perusahaan aneka industri yang terdaftar di Bursa Efek Indonesia (BEI) tahun 2014-2017. Sementara debt to equity ratio secara parsial berpengaruh negatif signifikan terhadap return on equity dan total assets turnover berpengaruh positif signifikan terhadap return on equity pada perusahaan aneka industri yang terdaftar di Bursa Efek Indonesia (BEI )tahun 2014-2017. Analisis yang dilakukan secara simultan menunjukkan bahwa inventory turnover, current ratio, debt to equity ratio, total assets turnover, dan working capital turnover berpengaruh positif dan signifikan terhadap return on equity pada perusahaan aneka industri yang terdaftar di Bursa Efek Indonesia (BEI) tahun 2014-2017.

\subsection{Keterbatasan}

Beberapa keterbatasan yang terdapat adalah penelitian ini hanya menguji rasio keuangan sebagai variabel independen yang mempengaruhi profitabiltias serta pemilihan objek penelitian hanya menggunakan sektor aneka industri.

\subsection{Saran}

Penelitian yang dilakukan ini menyimpulkan bahwa debt to equity ratio dan total assets turnover berpengaruh signifikan terhadap return on equity, sehingga disarankan kepada peneliti selanjutnya untuk menggunakan kedua variabel tersebut sebagai acuan dan mengembangkan penelitian ini kearah yang lebih baik. Pada masa mendatang, diharapkan kepada peneliti selanjutnya untuk dapat mengambil variabel lain untuk menilai kinerja perusahaan seperti return on asset, harga saham, dan lainnya. Perusahaan sebaiknya memperhatikan hutang dan 
penjualan karena kedua hal tersebut mempengaruhi tingkat profitabilitas. Investor akan lebih tertarik pada perusahaan yang mempunyai kondisi keuangan yang baik dan stabil.

\section{Daftar Pustaka}

Fahmi, Irham. 2017. Analisis Laporan Keuangan. Bandung : Alfabeta.

Felany, I. A., \& Worokinasih, S. 2018. Pengaruh Perputaran Modal Kerja, Leverage, dan Likuidias Terhadap Profitabilitas (Studi Pada Perusahaan Sub Sektor Makanan dan Minuman yang Terdaftar di Bursa Efek Indonesia pada Tahun 2012-2016). Jurnal Administrasi Bisnis Vol.58, No.2.

Ghozali, Imam. 2016. Aplikasi Analisi Multivariate dengan Program IBM SPSS 23. Semarang : Badan Penerbit Universitas Diponegoro.

Hantono. 2015. Pengaruh Current Ratio dan Debt to Equity Ratio Terhadap Profitabilitas Pada Perusahaan Manufaktur Sektor Logam dan Sejenisnya Yang Terdaftar di Bursa Efek Indonesia Periode 2009-2013. Jurnal Wira Ekonomi Mikroskil Vol.5, No.1.

Hendawati, H. 2017. Analisis Current Ratio, Debt to Equity Ratio dan Total Asset Turn Over Terhadap Return on Equity. Jurnal Sikap Vol.1, No.2.

Kasmir. 2015. Analisis Laporan Keuangan. Jakarta : PT RajaGrafindo Persada.

Mega, Ribka. 2017. Pengaruh Perputaran Piutang dan Perputaran Persediaan Terhadap Return on Equity (ROE) Pada PT Indofood Sukses Makmur Tbk dan Entitas Anak. Jurnal FinAcc Vol.1, No.9.

Nopita, M., \& Ernawati. 2018. Analisis Current Ratio dan Working Capital Turnover dan Pengaruhnya Terhadap Profitabilitas Pada PT. Unilever Indonesia, Tbk. Jurnal Scientific Vol.1, No.2.

Pongrangga,dkk. 2015. Pengaruh Current Ratio, Total Aset Turnover dan Debt to Equity Ratio Terhadap Return on Equity (Studi pada Perusahaan Sub Sektor Property dan Real Estate yang Terdaftar di BEI periode 2011-2014). Jurnal Administrasi Bisnis (JAB) Vol.25, No.2.

Pratomo, Adityo Joko. 2017. Pengaruh Debt to Equity Ratio (DER) dan Current Ratio (CR) Terhadap Return on Equity (ROE). Studi Empiris Pada Perusahaan Sub Sektor Kabel Yang Terdaftar di Bursa Efek Indonesia Pada Tahun 2013-2016. eJournal Administrasi Bisnis ISSN 2355-5408.

Sanada, A.B. 2016. Pengaruh Perputaran Modal Kerja Terhadap Return on Equity, Return on Investment, dan Debt to Equity Ratio Pada PT Gemilang Surya Motorindo di Pontianak. Jurnal BIS-MA Vol.1, No.2.

Susanti. 2017. Pengaruh Perputaran Piutang dan Perputaran Persediaan Terhadap Return on Equity Pada PT Catur Sentosa Adiprana, Tbk dan Entitas Anak. Jurnal FinAcc Vol.1, No.12.

Susilawati,dkk. 2017. Pengaruh Perputaran Persediaan dan Perputaran Total Aset Terhadap Profitabilitas Pada PT. Indofarma (Persero) Tbk. STAR-Study \& Accounting Research Vol.XIV, No.1, ISSN 1693-4482. 